\title{
Total digestible nutrient levels in supplements for finishing steers in the rainy season: nutritional characteristics and microbial efficiency
}

\author{
Jefferson Fabiano Werner Koscheck ${ }^{1}$, Joanis Tilemahos Zervoudakis ${ }^{1,2}$, Luciana Keiko \\ Hatamoto Zervoudakis ${ }^{1,2}$, Luciano da Silva Cabral ${ }^{1,2}$, André Alves de Oliveira ${ }^{1}$, João Marcos \\ Beltrame Benatti ${ }^{1}$, Daniel Marino Guedes de Carvalho ${ }^{1}$, Renata Pereira da Silva ${ }^{1}$
}

\footnotetext{
${ }^{1}$ Programa de Pós-Graduação em Ciência Animal, Universidade Federal de Mato Grosso, Cuiabá, MT, Brasil.

${ }^{2}$ Pesquisador Membro INCT-CA.
}

\begin{abstract}
The objective of this study was to evaluate the effects of total digestible nutrient (TDN) levels in supplements on rumen $\mathrm{pH}$, ruminal ammonia nitrogen concentration, intake and digestibility, nitrogen balance and microbial efficiency in beef cattle grazing on Marandu grass during the rainy season. The supplements comprised a mineral mixture, ground corn grain, soybean hulls, roasted soybeans and urea:ammonium sulfate. The mineral mix (MM) and supplements were supplied at $800,1,600$ and 2,400 g/animal/day, contained 500, 1,000 and 1,500 g of TDN, respectively, and were termed S500, S1000 and $\mathrm{S} 1500$. Supplemental crude protein (CP) was fixed at $300 \mathrm{~g}$ animal/day for all supplementing strategies. Four crossbred rumenfistulated steers, with an average weight of $512 \mathrm{~kg}$, were utilized. The animals were distributed in a $4 \times 4$ Latin square in four paddocks of 0.25 ha. The rumen nitrogen concentration was increased by $63 \%$ after four hours of supplementation. Supplements with increased TDN levels did not alter the total dry matter and forage intakes, although the TDN levels linearly increased the non-fibrous carbohydrates intake. Additionally, most supplements did not alter the digestibility of the diet nutrients. The nitrogen balance was similar in all treatments. However, supplements with the highest TDN levels linearly improved the microbial efficiency of finishing beef cattle that were pasture-grazed during the rainy season. Supplements with increasing TDN levels improve the microbial efficiency during the rainy season.
\end{abstract}

Key Words: digestibility, intake, ruminant, synthesis of microbial protein

\section{Introduction}

Dietary supplementation during the dry season is commonly used by farmers because of the high cost-benefit relationship involved (Baião et al., 2005). Conversely, farmers consider supplementation during the rainy season unnecessary because tropical forage has a higher level of crude protein $(\mathrm{CP})$ during this period, usually $7 \%$ greater than in the dry season (Leng, 1984).

However, the genetic potential of the animals is not attained when a mineral mix is used alone, as suggested by an additional weight gain exhibited by supplemented animals, approximately $200 \mathrm{~g} / \mathrm{animal} / \mathrm{day}$ (Paulino et al., 2008). This latent weight gain is associated with the equilibrium between the release of protein and energy in the rumen obtained from degrading forage and the supplement (Poppi \& McLennan, 1995).

Detmann et al. (2010) reported that most published data indicate that forage harvested in tropical pastures under continuous management exhibits total digestible nutrient/CP ratios above the nutritional requirements recommended by Valadares Filho et al. (2006). This observation demonstrates that most experiments performed during the rainy season require dietary supplements containing rumen-degradable protein. Energy-exclusive supplementation would lead to metabolic discomfort, which would result in the animal ingesting a large forage mass via a small supplement amount.

Notably, high levels of management are necessary for tropical forages to exhibit a CP content greater than $15 \%$. In such situations, a high proportion of fraction A of the $\mathrm{CP}$, which is quickly absorbed by the rumen, is represented mainly by non-protein nitrogen (NPN) (Sniffen et al., 1992). Within this context, a high availability of energy from neutral detergent fiber (NDF) does not result in high degradation of forage NPN, resulting in low nitrogen assimilation by ruminal microorganisms. In this case, energy supplementation would boost animal performance by increasing nitrogen retention (Poppi \& McLennan, 1995).

For these reasons, the objective of this study was to evaluate the nutritional parameters and efficiency of microbial protein synthesis of steers while grazing on pasture during the rainy season and receiving supplements with various levels of TDN. 


\section{Material and Methods}

The experiment was performed in the beef cattle sector located in the municipality of Santo Antônio do Leverger, close to coordinates $15^{\circ} 47^{\prime} 5^{\prime \prime}$ South and $56^{\circ} 04^{\prime}$ West, at an altitude of 140 meters; the study was conducted during the rainy season from February to April (Table 1).

Four rumen-cannulated crossbred $1 / 2$ European $\times$ Zebu castrated steers with an average body weight (BW) of $512.75 \mathrm{~kg}$ and a mean age of 36 months were used. The experimental area comprised 0.24 ha paddocks covered uniformly with Marandu grass (Brachiaria brizantha cv. Marandu) and harboring a covered feeder and drinker. The mean stocking rate was $4.55 \mathrm{AU} / \mathrm{ha}$.

The experiment was structured in a Latin square design, with three supplementation levels, 800, 1,600 and 2,400 g/animal/day, termed S500, S1000 and S1500, respectively, and a mineral mixture (MM) only, four animals and four experimental periods. Each experimental period lasted 17 days as follows: forage was collected and the animals were adapted to the supplemented forage on days 1-5; chromium oxide was applied as an external marker on days 6-14; feces were collected on days 13-15; blood and urine were collected on the day 16 ; and rumen fluid was collected on day 17 .

Table 1 - Mean maximum and minimum temperatures $\left({ }^{\circ} \mathrm{C}\right)$ and precipitation $(\mathrm{mm})$ from January to April

\begin{tabular}{lccc}
\hline \multirow{2}{*}{ Month } & \multicolumn{2}{c}{ Mean temperature $\left({ }^{\circ} \mathrm{C}\right)$} & \multirow{2}{*}{ Precipitation $(\mathrm{mm})$} \\
\cline { 2 - 3 } & Maximum & Minimum & \\
\hline January & 34.1 & 22.7 & 152.9 \\
February & 33.0 & 23.3 & 243.2 \\
March & 33.0 & 23.2 & 272.9 \\
April & 32.6 & 22.4 & 111.4 \\
\hline
\end{tabular}

Table 2 - Supplement composition on a natural matter basis $(\mathrm{g} / \mathrm{kg})$

\begin{tabular}{lcccc}
\hline \multirow{2}{*}{ Item } & \multicolumn{4}{c}{ Supplements } \\
\cline { 2 - 5 } & $\mathrm{MM}$ & $\mathrm{S} 500$ & $\mathrm{~S} 1000$ & $\mathrm{~S} 1500$ \\
\hline Soybean hulls & & 70 & 360 & 445 \\
Ground corn grain & - & 70 & 385 & 470 \\
Roasted soybeans $_{\text {Urea+ammonium sulfate }}(9: 1)$ & - & 750 & 200 & 50 \\
Mineral mixture $^{1}$ & 1,000 & 70 & 20 & 10 \\
$\mathrm{CP}^{2}$ & - & 375.00 & 187.50 & 125.00 \\
$\mathrm{TDN}^{2}$ & - & 625.00 & 625.00 & 625.00 \\
TDN:CP $^{2}$ & - & 1.66 & 3.33 & 4.97
\end{tabular}

MM - mineral mixture; CP - crude protein; TDN - total digestible nutrients; S500, $\mathrm{S} 1000$ and S1500 - supplements containing 500, 1,000 and 1,500 g of TDN, respectively.

${ }^{1}$ The commercial mineral supplement contained the following guaranteed levels: calcium - $198 \mathrm{~g}$; phosphorus - $60 \mathrm{~g}$; sodium - $117 \mathrm{~g}$; magnesium - $5.1 \mathrm{~g}$; sulfur - $12.6 \mathrm{~g}$; iodine - $17.7 \mathrm{mg}$; iron - $425 \mathrm{mg}$; selenium - $10.4 \mathrm{mg}$; cobalt - $80 \mathrm{mg}$; manganese - $527 \mathrm{mg}$; fluorine - $600 \mathrm{mg}$; copper - $1,000 \mathrm{mg}$ and zinc $-3,000 \mathrm{mg}$.

${ }^{2}$ Estimated based on the values of Tabela de Composição de Alimentos para Bovinos (Valadares Filho et al., 2002)
The animals received approximately 500, 1,000 and $1,500 \mathrm{~g}$ of TDN/animal/day, corresponding to the treatments S500, S1000 and S1500, respectively. Each animal received $300 \mathrm{~g}$ of CP each day, and a control group received only MM (Table 2).

Supplements were placed in individual troughs daily at 10h00, and any leftovers were monitored. The supplements were sampled for chemical analyses (Table 3).

On the first day of each experimental period, three forage samples were collected by cutting $5 \mathrm{~cm}$ above the soil level on an area delimited by a $0.5 \times 0.5 \mathrm{~m}$ metallic square. After collection, the samples from each paddock were weighed and homogenized, and two composite aliquots were obtained from these samples: one for evaluating the leaf mass (LM)/ha and potentially digestible dry matter (pDDM) and one for fractioning the plant structural components and further analysis of the availability/ha of dry matter of green leaf blade (DMGLB), dry leaf blade (DMDLB), green stem (DMGS) and dry stem (DSDM). The forage consumed by animals was sampled via a manual grazing simulation, which was conducted on the first day of each experimental period; in total, 16 samples were harvested.

Neutral detergent-insoluble residue (iNDF) was assessed in the samples that were collected to estimate LM. The residue was evaluated after the samples were incubated in situ for 240 hours (Casali et al., 2008) to calculate the percentage of pDDM available to the animals, according to Paulino et al. (2006)

To estimate dry fecal excretion matter, $15 \mathrm{~g}$ of chromium oxide was supplied daily from days 6-14 of each experimental period directly into the rumen of each animal in a single dose at $11 \mathrm{~h} 00$. Fecal matter was sampled on

Table 3 - Chemical composition of experimental supplements

\begin{tabular}{|c|c|c|c|}
\hline \multirow{2}{*}{ Item } & \multicolumn{3}{|c|}{ Supplements } \\
\hline & S500 & $\mathrm{S} 1000$ & $\mathrm{~S} 1500$ \\
\hline Dry matter ${ }^{1}$ & 917.6 & 891.7 & 897.7 \\
\hline Organic matter ${ }^{2}$ & 877.1 & 938.2 & 949.1 \\
\hline Crude protein ${ }^{2}$ & 367.0 & 173.5 & 122.0 \\
\hline Ether extract ${ }^{2}$ & 132.0 & 104.0 & 90.6 \\
\hline $\mathrm{Ash}^{2}$ & 122.9 & 61.8 & 50.9 \\
\hline Total carbohydrates ${ }^{2}$ & 370.1 & 646.7 & 733.5 \\
\hline Non-fibrous carbohydrates ${ }^{2}$ & 244.9 & 418.3 & 454.6 \\
\hline Indigestible neutral detergent fiber $^{2}$ & 78.5 & 77.1 & 69.5 \\
\hline Neutral detergent fiber ${ }^{2}$ & 270.8 & 360.6 & 411.8 \\
\hline Acid detergent fiber ${ }^{2}$ & 126.6 & 179.3 & 220.9 \\
\hline $\begin{array}{l}\text { Neutral detergent fiber corrected } \\
\text { for ash and protein }{ }^{2}\end{array}$ & 237.2 & 340.4 & 390.9 \\
\hline Neutral detergent insoluble nitrogen ${ }^{3}$ & 164.4 & 150.7 & 195.7 \\
\hline Acid detergent insoluble nitrogen ${ }^{3}$ & 100.1 & 74.4 & 67.2 \\
\hline
\end{tabular}


the 13th, 14th and 15th days, at 16h00, $12 \mathrm{~h} 00$ and $08 \mathrm{~h} 00$, respectively. Immediately after collection, the fecal samples were identified and frozen at $-20{ }^{\circ} \mathrm{C}$.

Subsequently, the fecal samples and manually simulated pasture samples were pre-dried in an oven. Next, the samples were weighed, ground in a mill with a 1-mm-pore diameter sieve and stored as composite samples per animal in a given period in bags that were properly identified for laboratory analyses.

Fecal DM excretion was estimated based on the ratio between the amount of the marker provided $(\mathrm{g})$ and its concentration in the feces $(\mathrm{g} / \mathrm{kg}$ fecal DM).

The equation proposed by Detmann et al. (2001) was used to estimate the voluntary DM intake of the animals, and the iNDF was adopted as an internal marker. The simulated grazing, supplement and fecal samples were incubated for 240 hours (Casali et al., 2008) in the rumen of a crossbred bovine weighing $500 \mathrm{~kg}$; the rumen was fistulated and cannulated to estimate the iNDF.

On the 16th day, four hours after the supplements were offered, blood and urine were sampled to assess urea and creatinine levels. The blood samples were centrifuged at 4,000 rpm for 15 minutes to obtain the serum, which was frozen at $-20{ }^{\circ} \mathrm{C}$ for subsequent quantification of the urea contents (Valadares et al., 1999).

Urine was collected via spontaneous urination. Two aliquots were stored in the form of spot samples. The first aliquot was used to assess the concentrations of creatinine, uric acid and allantoin; this sample comprised $10 \mathrm{~mL}$ of urine and $40 \mathrm{~mL}$ of $0.036 \mathrm{~N}$ sulfuric acid. The second aliquot comprising $50 \mathrm{~mL}$ of pure urine was used to determine the urea concentration.

Urine volume was estimated by multiplying the animal live weight ( $\mathrm{kg}$ of $\mathrm{LW})$ by the daily creatinine excretion $(\mathrm{mg} / \mathrm{kg} \mathrm{LW})$ and dividing the product by the creatinine concentration $(\mathrm{mg} / \mathrm{L})$ in the urea. To calculate the daily creatinine excretion per $\mathrm{kg}$ of $\mathrm{LW}$, the mean of $27.76 \mathrm{mg} / \mathrm{kg}$ LW obtained by Rennó (2003) was adopted.

Daily excretion was calculated as the product of the urea concentration and the urinary volume after 24 hours, which was then multiplied by 0.466 , corresponding to the nitrogen content in the urea (Rennó et al., 2000).

The amount of nitrogen absorbed was obtained from the difference between the nitrogen ingested and the nitrogen excreted in the feces, whereas the nitrogen balance (NB) was obtained from the difference between the nitrogen ingested and the nitrogen excreted in the feces and urine.

Allantoin in the diluted urine spot was analyzed using the colorimetric method according to the method of Fujihara et al. (1987) as described by Chen \& Gomes (1992). The total excretion of purine derivatives was calculated from the sum of the quantities of allantoin and uric acid excreted in the urine, expressed as $\mathrm{mmol} / \mathrm{day}$.

Absorbed purines (X, mmol/day) were estimated from the excretion of purine derivatives ( $\mathrm{Y}, \mathrm{mmol} /$ day) using the following equation:

$$
Y=0.85 X+0.385 L W^{0.75}
$$

in which: 0.85 is the recovery of absorbed purine as purine derivatives, and $0.385 \mathrm{LW}^{0.75}$ is the endogenous contribution to the purine excretion (Verbic et al., 1990). The ruminal synthesis of nitrogenous compounds ( $\mathrm{Y}, \mathrm{gN} /$ day) was calculated based on the amount of absorbed purines (X, $\mathrm{mmol} /$ day) according to the equation proposed by Chen \& Gomes (1992).

To determine the $\mathrm{pH}$ and concentration of ruminal ammonia nitrogen $\left(\mathrm{N}-\mathrm{NH}_{3}\right)$ in the rumen fluid, samples were collected manually, from the liquid/solid interface of the rumen environment on the 17th day of the experimental period, immediately before supplementation and 4 hours after the supplementation. The $\mathrm{pH}$ was measured immediately after collection using a digital $\mathrm{pH}$ meter. The ammonia concentration was assessed from a $50-\mathrm{mL}$ aliquot of rumen fluid that was separated and fixated with $1 \mathrm{~mL}$ of sulfuric acid $\left(\mathrm{H}_{2} \mathrm{SO}_{4}\right)$ at a 1:1 ratio, conditioned in a lidded plastic container, identified and frozen at $-20{ }^{\circ} \mathrm{C}$.

To relate the intake to animal $\mathrm{BW}$, the average weights over the experimental periods were estimated based on the initial and final weights of each period.

Dry matter, organic matter $(\mathrm{OM})$, crude protein $(\mathrm{CP})$, neutral detergent fiber (NDF), acid detergent fiber (ADF), neutral detergent fiber corrected for ash and protein (NDFap), ether extract (EE) and ash contents were assessed in the fecal samples, in the forage obtained by manually simulated animal grazing and in the supplements. The neutral detergent insoluble nitrogen (NDIN) and acid detergent insoluble nitrogen (ADIN) contents of the forage and supplement samples were assessed according to Silva \& Queiroz (2002).

The non-fibrous carbohydrate (NFC) contents of the supplements were assessed according to Hall (2000) with some modifications due to the inclusion of urea in the supplement. The total carbohydrate (CT) contents of the feedstuffs were calculated according to Sniffen et al. (1992).

Based on the feedstuff chemical composition, the total digestible nutrient (TDN) contents were assessed according to the NRC (2001), which estimates the values of digestible crude protein (DCP), digestible fatty acids (DFA), neutral detergent fiber corrected for digestible protein (NDFDp) and digestible non-fibrous carbohydrates (DNFC). 
The data were analyzed by regression using the GLM procedure of the SAS (Statistical Analysis System, version 9.2) software package, and results were considered significant at the 0.05 level.

\section{Results and Discussion}

Mean availabilities of 7,244, 5,297, 1,935, 850, 4,289 and $168 \mathrm{~kg} / \mathrm{ha}$ were measured for use in calculating the forage mass, potentially digestible dry matter and the dry matter contents of green leaf blades, dry leaf blades, green stems and dry stems, respectively.

The mean availability of dry matter of green leaf blades was $1,935 \mathrm{~kg} / \mathrm{ha}$, which was sufficient for the forage intake of the animals. According to Euclides et al. (1992), a mean availability of $1,108 \mathrm{~kg} / \mathrm{ha}$ of green leaf blades does not limit the forage intake.

The CP content of the forage grass available for grazing was always greater than $110 \mathrm{~g} / \mathrm{kg} \mathrm{DM}$, and a mean value of $120 \mathrm{~g} / \mathrm{kg}$ DM was observed (Table 4). This value was higher than the value of $70 \mathrm{~g} / \mathrm{kg}$ DM recommended by Van Soest (1994) to meet the minimum nitrogenous compound requirements so that the activity of the rumen microorganisms is not limited.

Although a high forage CP content was observed, it should be noted that part of this $\mathrm{CP}$ is not available to the animal or is slowly liberated, as verified by the acid and neutral detergent insoluble nitrogen (ADIN and NDIN, respectively) levels of 133.1 and $228.9 \mathrm{~g} / \mathrm{kg}$ total nitrogen, respectively. Thus, it is important to supplement the forage with rumen-degradable protein (RDP) during the rainy season.
The mean values of neutral and acid detergent fibers (NDF and ADF, respectively) in the samples collected via manual simulation of grazing were 664.6 and $302.4 \mathrm{~g} / \mathrm{kg} \mathrm{DM}$, respectively; these values are typical of tropical grasses, mainly due to the iNDF value of $200.9 \mathrm{~g} / \mathrm{kg}$ DM.

Supplementing with diets representing different energy levels did not significantly alter $(\mathrm{P}>0.05)$ the intakes of total dry matter (TDM), forage dry matter (FDM), total organic matter (TOM), forage organic matter (FOM), crude protein (CP), total carbohydrates (TC) or NDF (Table 5). However, the intakes of ether extract (EE) and non-fiber carbohydrates (NFC) differed linearly between treatments $(\mathrm{P}<0.05)$. The higher NFC intake can be explained by the higher levels of supplementation, with increases of 244.9, 418.3 and $454.6 \mathrm{~g} / \mathrm{kg}$ of supplement for treatments S500, S1000 and S1500, respectively.

Although a significant difference was not observed for the $\mathrm{CP}$ intake, a numerical difference was observed, likely because all supplemented animals received $300 \mathrm{~g}$ of $\mathrm{CP}$ daily.

Dry matter intake is the main component that determines the food intake (substrate) in the rumen. However, this intake negatively correlates with cell wall components when NDF levels are higher than $55-60 \%$. This is true because the disappearance of rumen NDF is time-dependent (Ellis et al., 1994). Additionally, for the animal to consume additional fibrous material, the material remaining from the previous meal must be removed from the rumen (steady state) either by passing or by digestion.

Moore et al.(1999) emphasized that forages with TDN/CP ratios of less than 7.00 would contain excess $\mathrm{N}$ and that the use of supplements would decrease voluntary forage intake,

Table 4 - Mean chemical composition of Marandu grass samples obtained from a manual simulation of grazing during the rainy season

\begin{tabular}{|c|c|c|c|c|c|}
\hline \multirow{2}{*}{ Item } & \multicolumn{5}{|c|}{ Experimental months } \\
\hline & Feb 12th & Feb 28th & Mar 17th & Apr 3rd & Mean \\
\hline Dry matter ${ }^{1}$ & 311.2 & 307.3 & 300.0 & 293.7 & 303.0 \\
\hline Organic matter ${ }^{2}$ & 947.4 & 937.8 & 933.0 & 923.4 & 935.4 \\
\hline Crude protein ${ }^{2}$ & 119.6 & 112.5 & 119.6 & 128.4 & 120.0 \\
\hline Ether extract ${ }^{2}$ & 42.2 & 40.6 & 37.2 & 39.3 & 39.8 \\
\hline $\mathrm{Ash}^{2}$ & 52.6 & 62.2 & 67.0 & 76.6 & 64.6 \\
\hline Total carbohydrates $^{2}$ & 785.6 & 784.7 & 776.2 & 755.6 & 775.5 \\
\hline Non-fibrous carbohydrates ${ }^{2}$ & 153.5 & 158.4 & 142.9 & 121.0 & 143.9 \\
\hline Indigestible neutral detergent fiber ${ }^{2}$ & 190.0 & 199.0 & 207.3 & 207.2 & 200.9 \\
\hline Neutral detergent fiber ${ }^{2}$ & 664.3 & 658.6 & 660.8 & 674.6 & 664.6 \\
\hline Acid detergent fiber ${ }^{2}$ & 279.8 & 305.6 & 301.5 & 322.6 & 302.4 \\
\hline Neutral detergent fiber corrected for ash and protein ${ }^{2}$ & 632.1 & 626.3 & 633.3 & 634.3 & 631.5 \\
\hline Lignin $^{2}$ & 39.8 & 38.1 & 40.3 & 42.2 & 40.1 \\
\hline Neutral detergent insoluble nitrogen ${ }^{3}$ & 214.3 & 222.4 & 254.2 & 224.6 & 228.9 \\
\hline Acid detergent insoluble nitrogen ${ }^{3}$ & 105.8 & 118.6 & 122.8 & 185.1 & 133.1 \\
\hline Total digestible nutrients ${ }^{2,4}$ & 658.7 & 648.2 & 637.4 & 623.6 & 642.0 \\
\hline
\end{tabular}

${ }^{1} \mathrm{~g} / \mathrm{kg}$ natural matter.

$\mathrm{g} / \mathrm{kg}$ dry matter.

${ }^{3} \mathrm{~g} / \mathrm{kg}$ total nitrogen.

${ }^{4}$ Estimated according to the NRC (2001). 
which would be evident in good quality forage. However, in low quality forage such as mulch, supplementation typically boosts forage intake. Nevertheless, in the present study, although the TDN/CP ratio was less than 7.00, forage intake did not decrease even when supplied at 2.4 $\mathrm{kg} / \mathrm{animal} /$ day. However, a trend toward decreasing forage intake with increasing supplementation was observed.

According to Herd (1997), forage mass is replaced by supplements when the level of supplementation is greater than $0.2 \%$ of BW. The author also noted that the substitution coefficient is $30 \mathrm{~g}$ of forage for every $100 \mathrm{~g}$ of supplement ingested. The substitution coefficient in the present study was similar to this recommendation and lay in the range from 20.00 to $41.87 \mathrm{~g}$.

Supplements with different energy contents did not alter $(\mathrm{P}>0.05)$ the total apparent digestibility of $\mathrm{DM}, \mathrm{OM}, \mathrm{CP}$, EE, NDF, TC or NFC (Table 6). Thus, as the digestibility of the diet (withdrawal of mass rumen) did not differ with increasing supplementation in the present study, a higher voluntary DM intake was not expected.

The results (Table 7) indicate that increased supplement levels did not decrease the ruminal $\mathrm{pH}$ below the minimum

Table 5 - Nutrient intake in finishing cattle during the rainy season

\begin{tabular}{|c|c|c|c|c|c|c|c|c|c|}
\hline \multirow{2}{*}{ Item } & \multicolumn{4}{|c|}{ Supplements } & \multicolumn{3}{|c|}{$\mathrm{P}$-value } & \multirow{2}{*}{ CV $(\%)$} & \multirow{2}{*}{$\mathrm{R}^{2}$} \\
\hline & MM & S500 & $\mathrm{S} 1000$ & $\mathrm{~S} 1500$ & Linear & Quadratic & Cubic & & \\
\hline Total dry matter ${ }^{1}$ & $10.22 \pm 1.85$ & $10.86 \pm 1.47$ & $11.15 \pm 1.19$ & $12.11 \pm 1.54$ & ns & ns & ns & 25.59 & 0.75 \\
\hline Forage dry matter ${ }^{1}$ & $10.22 \pm 1.85$ & $10.06 \pm 1.47$ & $9.55 \pm 1.19$ & $9.71 \pm 1.54$ & ns & ns & ns & 27.98 & 0.74 \\
\hline Total organic matter ${ }^{1}$ & $9.50 \pm 1.76$ & $10.11 \pm 1.39$ & $10.41 \pm 1.07$ & $11.37 \pm 1.50$ & ns & ns & ns & 26.06 & 0.75 \\
\hline Forage organic matter ${ }^{1}$ & $9.50 \pm 1.76$ & $9.41 \pm 1.39$ & $8.90 \pm 1.07$ & $9.10 \pm 1.50$ & ns & ns & ns & 28.36 & 0.76 \\
\hline Crude protein ${ }^{1}$ & $1.22 \pm 0.23$ & $1.51 \pm 0.18$ & $1.45 \pm 0.15$ & $1.46 \pm 0.17$ & ns & ns & ns & 24.84 & 0.78 \\
\hline Ether extract ${ }^{1}$ & $0.41 \pm 0.08$ & $0.51 \pm 0.05$ & $0.55 \pm 0.04$ & $0.61 \pm 0.07$ & 0.0175 & ns & ns & 27.06 & 0.84 \\
\hline Neutral detergent fiber ${ }^{1}$ & $6.76 \pm 1.24$ & $6.90 \pm 0.97$ & $6.93 \pm 0.81$ & $7.44 \pm 1.02$ & ns & ns & ns & 26.43 & 0.75 \\
\hline Total carbohydrates $^{1}$ & $7.88 \pm 1.45$ & $8.10 \pm 1.16$ & $8.42 \pm 0.88$ & $10.22 \pm 1.28$ & ns & ns & ns & 27.42 & 0.74 \\
\hline \multirow[t]{2}{*}{ Non-fibrous carbohydrates ${ }^{1}$} & $1.46 \pm 0.29$ & $1.64 \pm 0.23$ & $2.03 \pm 0.15$ & $2.51 \pm 0.28$ & 0.0028 & ns & ns & 31.70 & 0.88 \\
\hline & \multicolumn{9}{|c|}{$\mathrm{g} / \mathrm{kg}$ Body weight } \\
\hline Total dry matter & $20.5 \pm 0.31$ & $21.5 \pm 0.27$ & $21.7 \pm 0.20$ & $23.1 \pm 0.27$ & ns & ns & ns & 22.70 & 0.74 \\
\hline Forage dry matter & $20.3 \pm 0.31$ & $19.9 \pm 0.27$ & $18.5 \pm 0.20$ & $18.5 \pm 0.27$ & ns & ns & ns & 25.68 & 0.74 \\
\hline Neutral detergent fiber & $13.5 \pm 0.21$ & $13.7 \pm 0.18$ & $13.5 \pm 0.14$ & $14.2 \pm 0.18$ & ns & ns & ns & 23.74 & 0.73 \\
\hline TDN/CP ratio of the diet & 5.25 & 4.54 & 4.85 & 5.20 & - & - & - & - & - \\
\hline Coefficient of substitution ${ }^{2}$ & - & 20.00 & 41.87 & 21.25 & - & - & - & - & - \\
\hline
\end{tabular}

$\mathrm{CV}$ - coefficient of variation; $\mathrm{R}^{2}$ - coefficient of determination of linear, quadratic or cubic equations; ns - non-significant.

$\mathrm{MM}, \mathrm{S} 500, \mathrm{~S} 1000$ and S1500 - mineral mix and supplements containing 500, 1,000 and 1,500 g of TDN, respectively.

${ }^{1} \mathrm{~kg} /$ animal/day.

${ }^{2}$ Coefficient of pasture substitution in $\mathrm{g} / 100 \mathrm{~g}$ of supplement consumed.

Table 6 - Total apparent digestibility, in $\mathrm{kg} / \mathrm{kg}$, of finishing cattle during the rainy season

\begin{tabular}{|c|c|c|c|c|c|c|c|c|c|}
\hline \multirow{2}{*}{ Item } & \multicolumn{4}{|c|}{ Supplements } & \multicolumn{3}{|c|}{ P-value } & \multirow{2}{*}{$\mathrm{CV}(\%)$} & \multirow{2}{*}{$\mathrm{R}^{2}$} \\
\hline & MM & S500 & $\mathrm{S} 1000$ & $\mathrm{~S} 1500$ & Linear & Quadratic & Cubic & & \\
\hline Dry matter & $0.483 \pm 3.56$ & $0.482 \pm 2.71$ & $0.502 \pm 2.23$ & $0.494 \pm 1.96$ & ns & ns & $\mathrm{ns}$ & 9.95 & 0.64 \\
\hline Organic matter & $0.532 \pm 4.03$ & $0.521 \pm 2.48$ & $0.541 \pm 2.45$ & $0.545 \pm 2.35$ & ns & ns & ns & 9.91 & 0.71 \\
\hline Ether extract & $0.420 \pm 7.97$ & $0.481 \pm 5.15$ & $0.458 \pm 6.27$ & $0.403 \pm 4.89$ & ns & $\mathrm{ns}$ & $\mathrm{ns}$ & 26.28 & 0.66 \\
\hline Neutral detergent fiber & $0.498 \pm 2.83$ & $0.497 \pm 2.67$ & $0.502 \pm 2.84$ & $0.506 \pm 2.65$ & ns & $\mathrm{ns}$ & $\mathrm{ns}$ & 9.86 & 0.62 \\
\hline Total carbohydrates & $0.539 \pm 3.74$ & $0.514 \pm 3.22$ & $0.544 \pm 2.65$ & $0.559 \pm 2.80$ & ns & ns & $\mathrm{ns}$ & 10.84 & 0.80 \\
\hline
\end{tabular}

$\mathrm{CV}$ - coefficient of variation; $\mathrm{R}^{2}$ - coefficient of determination of linear, quadratic or cubic equations; ns - non-significant.

MM, S500, S1000 and S1500 - mineral mix and supplements containing 500, 1,000 and 1,500 g of TDN, respectively.

Table 7 - Mean values of $\mathrm{pH}$ and ruminal ammonia nitrogen concentration (mg/dL) in rumen fluid before and 4 hours after feeding

\begin{tabular}{|c|c|c|c|c|c|c|c|c|c|c|}
\hline \multirow{2}{*}{ Variables } & \multirow{2}{*}{ Time (hours) } & \multicolumn{4}{|c|}{ Supplements } & \multicolumn{3}{|c|}{$\mathrm{P}$-value } & \multirow{2}{*}{ CV (\%) } & \multirow{2}{*}{$\mathrm{R}^{2}$} \\
\hline & & MM & S500 & S1000 & S 1500 & Linear & Quadratic & Cubic & & \\
\hline $\mathrm{pH}$ & Zero & $6.93 \pm 0.10$ & $6.62 \pm 0.10$ & $6.65 \pm 0.06$ & $6.96 \pm 0.02$ & 0.0079 & ns & $\mathrm{ns}$ & 5.08 & 0.95 \\
\hline $\mathrm{pH}$ & Four & $6.77 \pm 0.13$ & $6.74 \pm 0.14$ & $6.87 \pm 0.03$ & $6.63 \pm 0.06$ & ns & ns & ns & 2.03 & 0.87 \\
\hline $\mathrm{N}-\mathrm{NH}_{3}$ & Zero & $5.57 \pm 0.65$ & $8.09 \pm 1.04$ & $7.98 \pm 1.42$ & $7.00 \pm 0.94$ & ns & 0.0166 & ns & 33.37 & 0.90 \\
\hline $\mathrm{N}-\mathrm{NH}_{3}^{3}$ & Four & $6.12 \pm 0.47$ & $9.29 \pm 1.46$ & $9.95 \pm 1.62$ & $9.84 \pm 1.53$ & 0.0161 & ns & ns & 43.46 & 0.88 \\
\hline
\end{tabular}

$\mathrm{CV}$ - coefficient of variation; $\mathrm{R}^{2}$ - coefficient of determination of linear, quadratic or cubic equations; ns - non-significant.

MM, S500, S1000 and S1500- mineral mix and supplements containing 500, 1,000 and 1,500 g of TDN, respectively. 
required by the ruminal bacteria for adequate development. According to Van Soest (1994), when the $\mathrm{pH}$ is less than 6.0 , the population of microorganisms that degrade fiber decreases. This decrease occurs because cellulolytic bacteria are sensitive to $\mathrm{pH}$ values of less than 6.0 and are likely inhibited at $\mathrm{pHs}$ between 4.5 and 5.0. The adequate functional $\mathrm{pH}$ for these bacteria is approximately 6.7 . According to Reis et al. (2007), a decrease in $\mathrm{pH}$ to less than the ideal value is rarely observed under Brazilian conditions; however, the supplementation levels are low, and the animals consume large amounts of fiber from forage.

All treatments displayed ruminal concentrations of $\mathrm{N}^{-\mathrm{NH}_{3}}$ (Table 7) less than the recommended values for animals under tropical conditions. Leng (1990) and Lazzarini (2007) recommend a concentration of $10.0 \mathrm{mg} / \mathrm{dL}$ of ruminal liquid. Concentrations that are less than the minimum concentrations required for cell wall degradation are not expected to increase the digestibility of the NDF fraction. Thus, the level of ruminal fill can control the DM intake for all treatments.

The formulation of the supplement was based on BR CORTE (Valadares Filho et al., 2006), in which the requirements of an uncastrated Nellore male of $450 \mathrm{~kg} / \mathrm{BW}$ with gains of $1 \mathrm{~kg} /$ day were estimated; to obtain this performance, the animal had to consume approximately $5.29 \mathrm{~kg}$ of TDN and $1.113 \mathrm{~kg}$ of $\mathrm{CP} /$ day. The $\mathrm{CP}$ intake of the animals receiving the MM only was higher than the amounts recommended by Valadares Filho et al. (2006). However, part of forage $\mathrm{CP}$ is either unavailable or slowly available and occurs in the form of acid or neutral detergent insoluble protein, which may result in low concentrations of ruminal ammonia nitrogen (RAN). Such conditions would not improve the microbial protein production and would possibly not satisfy performance requirements of $1 \mathrm{~kg} /$ day.

Supplementation with $300 \mathrm{~g}$ of CP per animal with increasing levels of TDN promoted a ruminal ammonia nitrogen concentration approximately $63 \%$ higher than in animals receiving the $\mathrm{MM}$ only $(6.12 \mathrm{mg} / \mathrm{dL})$ within four hours after supplementation.

Supplementation linearly altered the ingestion of nitrogen, fecal nitrogen and serum urea $(\mathrm{P}<0.05)$ and quadratically altered urine nitrogen, urine urea and absorbed nitrogen $(\mathrm{P}<0.05)$. However, the nitrogen balance remained unchanged $(\mathrm{P}>0.05)$ (Table 8).

Ammonia that is produced but not utilized in the rumen is absorbed, transformed into urea in the liver and returned into the circulation, from where it can return to the rumen via saliva or the rumen wall, and any excess is excreted in the urine (Reis et al., 2006). Van Soest (1994) reported that the concentration of urea in the urine likely correlates with $\mathrm{N}$ concentrations in the plasma and with $\mathrm{N}$ ingestion.

Maximum microbial production occurs when the concentration of urea in the serum is between 13 and $15 \mathrm{mg} / \mathrm{dL}$ (Valadares et al., 1997). In the same context, the supply of mineral mixture alone was not sufficient to maintain serum urea concentrations within these suggested values and therefore did not improve microbial protein production. Conversely, supplemented animals exhibited serum urea concentrations of higher than $15 \mathrm{mg} / \mathrm{dL}$ due to the inclusion of a protein supplement.

The amino acid composition of microbial protein is extremely similar to that of animal protein. Therefore, according to Vercbic (2002), microbial protein represents the best supplementation source to satisfy the amino acid requirements of the animals. Thus, the utilization of supplementation strategies that improve microbial production are important for intensive grazing cattle strategies as such supplements would increase the flow of protein of high biological value to the intestine and maximize animal performance.

The efficiency of synthesizing microbial nitrogenous compounds in the supplemented animals was similar to the reference values of $13 \mathrm{~g} \mathrm{CP} / 100 \mathrm{~g}$ TDN and $12 \mathrm{~g} \mathrm{CP} / 100 \mathrm{~g}$ TDN established by the NRC (2001) and by BR-CORTE (Valadares Filho et al., 2006), respectively.

Table 8 - Ingested and excreted nitrogen (g/day), nitrogen and urea in the urine (g/day), serum urea nitrogen ( $\mathrm{mg} / \mathrm{dL}$ ), absorbed nitrogen (g/day) and the nitrogen balance (g/day) of cattle supplemented during the rainy season

\begin{tabular}{|c|c|c|c|c|c|c|c|c|c|}
\hline \multirow{2}{*}{ Item } & \multicolumn{4}{|c|}{ Supplements } & \multicolumn{3}{|c|}{ P-value } & \multirow{2}{*}{$\mathrm{CV}(\%)$} & \multirow{2}{*}{$\mathrm{R}^{2}$} \\
\hline & $\mathrm{MM}$ & $\mathrm{S} 500$ & $\mathrm{~S} 1000$ & $\mathrm{~S} 1500$ & Linear & Quadratic & Cubic & & \\
\hline Ingested nitrogen & $195.61 \pm 24.30$ & $241.53 \pm 18.87$ & $231.78 \pm 16.52$ & $233.46 \pm 18.46$ & 0.0462 & ns & ns & 24.84 & 0.78 \\
\hline Nitrogen in the urine & $6.15 \pm 1.25$ & $32.63 \pm 6.73$ & $24.39 \pm 4.42$ & $21.45 \pm 2.51$ & 0.0052 & $<.0001$ & 0.0033 & 71.13 & 0.81 \\
\hline Urea in the urine & $13.19 \pm 2.70$ & $70.03 \pm 14.45$ & $52.34 \pm 9.49$ & $46.03 \pm 5.39$ & 0.0052 & $<.0001$ & 0.0033 & 71.14 & 0.81 \\
\hline Excreted nitrogen (feces) & $55.50 \pm 3.96$ & $74.01 \pm 6.41$ & $75.81 \pm 5.08$ & $96.49 \pm 7.70$ & $<.0001$ & ns & ns & 28.86 & 0.76 \\
\hline Urea in the serum & $8.00 \pm 1.11$ & $16.38 \pm 1.55$ & $16.50 \pm 2.09$ & $19.50 \pm 1.75$ & $<.0001$ & 0.0198 & 0.0297 & 41.40 & 0.83 \\
\hline Absorbed nitrogen & $140.11 \pm 20.62$ & $167.52 \pm 13.31$ & $155.97 \pm 12.11$ & $136.97 \pm 10.85$ & ns & 0.0087 & ns & 27.65 & 0.78 \\
\hline Nitrogen balance & $133.96 \pm 20.63$ & $134.88 \pm 11.12$ & $131.57 \pm 12.17$ & $115.52 \pm 10.83$ & ns & ns & ns & 30.27 & 0.84 \\
\hline
\end{tabular}

$\mathrm{CV}$ - coefficient of variation; $\mathrm{R}^{2}$ - coefficient of determination of linear, quadratic or cubic equations; ns - non-significant.

MM, S500, S1000 and S1500 - mineral mix and supplements containing 500, 1,000 and 1,500 $\mathrm{g}$ of TDN, respectively. 
Table 9 - Urinary excretion of total purines (TP) (mmol/day), absorbed microbial purine (AMP) (mmol/day), microbial nitrogen (MN) (g/day), microbial protein (MP) (g/day) and microbial efficiency (ME) (g micCP/100 g TDN) in supplements with various energy levels

\begin{tabular}{|c|c|c|c|c|c|c|c|c|c|}
\hline \multirow{2}{*}{ Item } & \multicolumn{4}{|c|}{ Supplements } & \multicolumn{3}{|c|}{ P-value } & \multirow{2}{*}{ CV (\%) } & \multirow{2}{*}{$\mathrm{R}^{2}$} \\
\hline & $\mathrm{MM}$ & $\mathrm{S} 500$ & $\mathrm{~S} 1000$ & $\mathrm{~S} 1500$ & Linear & Quadratic & Cubic & & \\
\hline Total purines & $158.27 \pm 1.19$ & $220.19 \pm 12.52$ & $248.98 \pm 10.82$ & $276.01 \pm 30.42$ & $<.0001$ & ns & ns & 28.5 & 0.72 \\
\hline Absorbed microbial purine & $138.82 \pm 1.77$ & $211.00 \pm 15.21$ & $244.18 \pm 12.66$ & $275.19 \pm 35.91$ & $<.0001$ & ns & ns & 34.72 & 0.72 \\
\hline Microbial nitrogen & $87.37 \pm 1.11$ & $132.80 \pm 9.57$ & $156.14 \pm 7.96$ & $173.20 \pm 22.60$ & $<.0001$ & 0.0196 & ns & 24.72 & 0.74 \\
\hline Microbial protein & $546.07 \pm 6.99$ & $830.01 \pm 59.85$ & $960.51 \pm 49.81$ & $1,082.50 \pm 141.28$ & $<.0001$ & ns & ns & 24.29 & 0.74 \\
\hline Microbial efficiency & $9.53 \pm 1.41$ & $12.99 \pm 2.05$ & $13.22 \pm 0.59$ & $13.54 \pm 1.73$ & 0.0117 & ns & ns & 36.28 & 0.71 \\
\hline
\end{tabular}

$\mathrm{CV}$ - coefficient of variation; $\mathrm{R}^{2}$ - coefficient of determination of linear, quadratic or cubic equations; ns - non-significant.

MM, S500, S1000 and S1500 - mineral mix and supplements containing 500, 1,000 and 1,500 g of TDN, respectively.

Animals receiving only the mineral mixture exhibited an efficiency of synthesizing microbial nitrogenous compounds of $9.53 \mathrm{~g} \mathrm{CP} / 100 \mathrm{~g}$ TDN (Table 9), which is less than the BR-CORTE reference value (Valadares Filho et al., 2006).

The greater synthesis of microbial nitrogenous compounds in the supplemented animals can be explained by the higher intake of NFC from the supplement. Nonfibrous carbohydrates can promote microbial growth more effectively than fibrous carbohydrates (cellulose and hemicellulose) due to its digestion rate, provided adequate nitrogen is available (Russell et al., 1992).

Additionally, NFC can more effectively promote microbial growth than fibrous carbohydrates (CF) because microorganisms that ferment $\mathrm{NFC}$ require $0.15 \mathrm{~g}$ carbohydrate/g cells/hour, which is three times greater than the requirement of $\mathrm{CF}$-fermenting microorganisms (0.05 g carbohydrate/g cell/hour) (Russell et al., 1992).

Crude protein supplementation (300 $\mathrm{g}$ of $\mathrm{CP} /$ animal/day) should be considered because microbial growth may be affected by the availability of factors that comprise the nutritional requirements of rumen microorganisms including nitrogenous compounds, such as ammonia, peptides and amino acids (Sniffen et al., 1993).

Thus, NFC and CP supplements contributed to increased microbial efficiency values of 12.99, 13.22 and 13.54 CP/100 g TDM for the supplements S500, S1000 and $\mathrm{S} 1500$, respectively. These values are similar to those recommended by Valadares Filho et al. (2006).

\section{Conclusions}

Supplements with increasing TDN levels do not affect the intake of total dry matter and forage, the digestibility of nutrients or the nitrogen balance. However, supplementation linearly improves the microbial efficiency of finishing beef cattle grazing during the rainy season.

\section{References}

BAIÃO, A.A.F.; ANDRADE, I.F.; BAIÃO, E.A.M. et al. Desempenho de novilhos mestiços nelore suplementados em pastagem com diferentes níveis de concentrado no período seco do ano. Ciência Agrotécnica, v.29, n.6, p.1258-1264, 2005.

CASALI, A.O.; DETMANN, E.; VALADARES FILHO, S.C. et al. Influência do tempo de incubação e do tamanho de partículas sobre os teores de compostos indigestíveis em alimentos e fezes bovinas obtidos por procedimentos in situ. Revista Brasileira de Zootecnia, v.37, n.2, p.335-342, 2008.

CHEN, X.B.; GOMES, M.J. Estimation of microbial protein supply to sheep and cattle basid on urinary excretion of purine derivatives-an overview of the technical details. Buchsburnd Aberdeen: Rowett Research Institute, 1992. 21p.

DETMANN, E.; PAULINO, M.F.; ZERVOUDAKIS, J.T. et al. Cromo e indicadores internos na estimação do consumo de novilhos mestiços, suplementados, a pasto. Revista Brasileira de Zootecnia, v.30, n.5, p.1600-1609, 2001.

DETMANN, E.; PAULINO, M.F.; VALADARES FILHO, S.C. Otimização do uso de recursos forrageiros basais. In: SIMPÓSIO DE PRODUÇÃO DE GADO DE CORTE, 7., 2010, Viçosa, MG. Anais... Viçosa, MG: DZO-UFV, 2010. p.191-240.

ELLIS, W.C.; MATIS, J.H.; HILL, T.M. et al. Methodology for estimating digestion and passage kinetics of forages. In: FAHEY Jr., G.C. (Ed). Forage quality, evaluation, and utilization. Madison, WI: American Society of Agronomy, 1994. p.682-756.

EUCLIDES, V.P.B.; MACEDO, M.C.M.; OLIVEIRA, M.P. Avaliação de diferentes métodos de amostragem [para se estimar o valor nutritivo de forragens] sob pastejo. Revista da Sociedade Brasileira de Zootecnia, v.21, n.4, p.691-702, 1992.

FUJIHARA, T.; ØRSKOV, E.R.; REEDS, P.J. et al. The effect of protein infusion on urinary excretion of purine derivatives in ruminants nourished by intragastric nutrition. Journal Agricultural Science, v.109, n.1, p.7-12, 1987.

HALL, M.B.; AKINYODE, A. Cottonseed hulls: working with with a novel fiber source. In: ANNUAL FLORIDA RUMINANT NUTRITION SYMPOSIUM, 11., 2000, Gainesville. Proceedings... Gainesville, 2000. p.179-186.

HERD, D.B. Mineral supplementation of beef cows in Texas. 1997. Available at: $<\mathrm{http} / / /$ repository.tamu.edu/bitstream/handle/1969.1/ 87645/pdf_329.pdf?sequence=1>. Accessed on: Apr. 18, 2012.

LAZZARINI, I.; DETMANN, E.; SAMPAIO, C.B. et al. Consumo, $\mathrm{pH}$ e concentração de nitrogênio amoniacal ruminal em bovinos alimentados com forragem de baixa qualidade recebendo níveis crescentes de compostos nitrogenados suplementares. In: REUNIÃO ANUAL DA SOCIEDADE BRASILEIRA DE ZOOTECNIA, 44., 2007, Jaboticabal. Anais... Jaboticabal, 2007. (CD-ROM)

LENG, R.A. Supplementation of tropical and subtropical pastures for ruminant production. In: GILCHRIST, F.M.C.; MACKIE, R.I. (Eds.) 
Herbivore nutrition in the subtropics and tropics. Craighall, South Africa: The Science Press Ltda, 1984. p.129-144.

LENG, R.A. Factors affecting the utilization of "poor-quality" forages by ruminants particularly under tropical conditions. Nutrition Research Review, v.3, n.3, p.277-303, 1990.

MOORE, J.E.; BRANT, M.H.; KUNKLE, W.E. et al. Effects of supplementation on voluntary forage intake, diet digestibility, and animal performance. Journal of Animal Science, v.77, suppl. 2/J, p.122-135, 1999.

NATIONAL RESEARCH COUNCIL - NRC. Nutrient requirements of dairy cattle. 7.ed. Washington, D.C.: National Academic, 2001. $381 \mathrm{p}$.

PAULINO, M.F.; DETMANN, E.; VALADARES FILHO, S.C. Suplementação animal em pasto: energética ou proteica? In: SIMPÓSIO SOBRE MANEJO ESTRATÉGICO DA PASTAGEM, 3., 2006, Viçosa, MG. Anais... Viçosa, MG, 2006. p.359-392.

PAULINO, M.F.; DETMANN, E.; VALENTE, E.E.L. et al. Nutrição de bovinos em pastejo. In: SIMPÓSIO SOBRE MANEJO ESTRATÉGICO DA PASTAGEM, 4., 2008, Viçosa, MG. Anais... Viçosa, MG: DZO-UFV, 2008. p.131-169.

POPPI, D.P.; McLENNAN, S.R. Protein and energy utilization by ruminants at pasture. Journal of Animal Science, v.73, n.1, p.278-290, 1995.

REIS, R.A.; TEIXEIRA, I.A.M.A.; SIQUEIRA, G.R. Impacto da qualidade da forragem na produção animal. In: REUNIÃO ANUAL DA SOCIEDADE BRASILEIRA DE ZOOTECNIA, 43., 2006, João Pessoa. Anais... João Pessoa, 2006. p.580-608.

REIS, R.A.; BERCHIELLE, T.T.; OLIVEIRA, A.P. et al. Efeito do uso de alto concentrado sobre a saúde e desempenho de animais zebu e cruzados mantidos em pastagens tropicais. In: SIMPOSIO DE NUTRIÇÃO DE RUMINANTES, 3., 2007, Botucatu. Anais... Botucatu, 2007. p.61-95.

RENNÓ, L.N.; VALADARES, R.F.D.; LEÃO, M.I. et al. Estimativa da produção de proteína microbiana pelos derivados de purina na urina em novilhos. Revista Brasileira de Zootecnia, v.29, n.4, p.1223-1234, 2000.

RENNÓ, L.N. Consumo, digestibilidade total e parcial, produção microbiana, parâmetros ruminais e excreções de uréia e creatinina em novilhos alimentados com dietas contendo quatro níveis de uréia ou dois de proteína. 2003. 252f. Tese (Doutorado em Zootecnia) - Universidade Federal de Viçosa, Viçosa, MG.

RUSSELL, J.B.; O'CONNOR, J.D.; FOX, D.G. et al. A net carbohydrate and protein system for evaluation cattle diets: ruminal fermentation. Journal of Animal Science, v.70, n.12, p.3551-3581, 1992.

SILVA, D.J.; QUEIROZ, A.C. Análise de alimentos (métodos químicos e biológicos). 3.ed. Viçosa, MG: Editora UFV, 2002. 235p.

SNIFFEN, C.J.; O'CONNOR, J.D.; Van SOEST, P.J. et al. A net carbohydrate and protein system for evaluating cattle diets: II. Carbohydrate and protein availability. Journal of Animal Science, v.70, n.11, p.3562-3577, 1992.

SNIFFEN, C.J.; BEVERLY, R.W.; MOONEY, C.S. et al. Nutrient requeriments versus supply in the dairy cow: strategies to account for variability. Journal Dairy Science, v.76, n.10, p.3160-3178, 1993.

VALADARES, R.F.D.; GONÇALVES, L.C.; SAMPAIO, I.B. et al. Níveis de proteína em dietas de bovinos 4. Concentrações de ureia plasmática e excreções de ureia e creatinina. Revista Brasileira de Zootecnia, v.26, n.6, p.1270-1278, 1997.

VALADARES, R.F.D.; BRODERICK, G.A.; VALADARES FILHO, S.C. et al. Effect of replacing alfalfa silage with high moisture corn on ruminal protein synthesis estimated from excretion of total purine derivatives. Journal of Dairy Science, v.82, n.11, p.2686-2696, 1999

VALADARES FILHO, S.C.; ROCHA JÚNIOR, V.R.; CAPPELLE, E.R. Tabelas brasileiras de composição de alimentos para bovinos. Viçosa, MG: UFV, DZO, DPI, 2002. 297p.

VALADARES FILHO, S.C.; PAULINO, P.V.R; MAGALHÃES, K.A. Exigências nutricionais de zebuínos e tabelas de composição de alimentos / BR-CORTE. Viçosa, MG: UFV, 2006. 142p.

VAN SOEST, P.J. Nutrition ecology of the ruminant. 2.ed. Ithaca: Cornell University, 1994. 476p.

VERBIC, J.; CHEN, X.B.; MACLEOD, N.A. et al. Excretion of purine derivatives by ruminants. Effect of microbial nucleic acid infusion on purine derivative excretion by steers. Journal of Agricultural Science, v.114, n.3, p.243-248, 1990. 